\title{
New records of Rickettsia bellii-infected ticks in Brazil
}

\section{Novos relatos de carrapatos infectados por Rickettsia bellii no Brasil}

\author{
Francisco Borges COSTA ${ }^{1}$; Amália Regina Mar BARBIERI'; Matias Pablo Juan SZABÓ2; \\ Vanessa Nascimento RAMOS ${ }^{1}$; Ubiratan PIOVEZAN ${ }^{3}$; Marcelo Bahia LABRUNA ${ }^{1}$ \\ ${ }^{1}$ Universidade de São Paulo, Faculdade de Medicina Veterinária e Zootecnia, São Paulo - SP, Brazil
${ }^{2}$ Universidade Federal de Uberlândia, Faculdade de Medicina Veterinária, Uberlândia - MG, Brazil
${ }^{3}$ Empresa Brasileira de Pesquisa Agropecuária (Embrapa Pantanal), Corumbá - MS, Brazil
}

\begin{abstract}
This study investigated the occurrence of rickettsial infection in ticks collected from wild animals in two areas of Brazil. Amblyomma dubitatum ticks were collected from a capybara (Hydrochoerus hydrochaeris) in Guarda-Mor municipality, state of Minas Gerais, and Amblyomma pseudoconcolor ticks were collected from a six-banded armadillo (Euphractus sexcinctus) in Corumbá municipality, state of Mato Grosso do Sul. Attempts to isolate rickettsia in Vero cell culture were performed with one A. dubitatum tick and one A. pseudoconcolor tick, which were previously shown by the hemolymph test to contain Rickettsia-like structures within their hemocytes. Rickettsiae were successfully isolated in Vero cell culture from the two tick species. The two isolates were identified as Rickettsia bellii, since gltA partial sequences were 99.9\%-100\% identical to corresponding sequences of $R$. bellii in GenBank. While there have been several previous reports of $R$. bellii infecting A. dubitatum ticks, we provide the first report for A. pseudoconcolor, which increases to 25 the number of $R$. bellii-infected tick species in the American continent.
\end{abstract}

Keywords: Amblyomma dubitatum. Amblyomma pseudoconcolor. Isolation.

\section{Resumo}

O presente trabalho investigou a ocorrência de infecção por Rickettsia em carrapatos coletados em animais selvagens de duas áreas do Brasil. Carrapatos da espécie Amblyomma dubitatum foram coletados de uma capivara (Hydrochoerus hydrochaeris) no município de Guarda-Mor, Minas Gerais, enquanto exemplares da espécie Amblyomma pseudoconcolor foram coletados de um tatu-peba (Euphractus sexcinctus) do município de Corumbá, Mato Grosso do Sul. Tentativas para isolar Rickettsia em cultura de células Vero foram realizadas com um exemplar de A. dubitatum e um de A. pseudoconcolor, que foram previamente positivos no teste de hemolinfa com estruturas semelhantes a Rickettsia visualizadas em seus hemócitos. Rickettsia foram isoladas com sucesso em culturas de células Vero a partir das duas espécies de carrapatos. Os dois isolados foram identificados como Rickettsia bellii, uma vez que suas sequências parciais do gene gltA foram 99,9-100\%, idênticas a sequências de R. bellii do GenBank. Embora haja vários relatos anteriores de $R$. bellii infectando $A$. dubitatum, este é o primeiro relato em $A$. pseudoconcolor, aumentando para 25 o número de espécies de carrapatos infectadas por $R$. bellii no continente americano.

Palavras-chave: Amblyomma dubitatum. Amblyomma pseudoconcolor. Isolamento.

Correspondence to:

Marcelo Bahia Labruna

Universidade de São Paulo, Faculdade de Medicina Veterinária

e Zootecnia, Departamento de Medicina Veterinária e Saúde

Animal

Av. Prof. Dr. Orlando Marques de Paiva, 87

CEP 05508-270, São Paulo, SP, Brazil

E-mail: labruna@usp.br

Received: 08/04/2016

Approved: 12/01/2017

The bacterial genus Rickettsia includes Gram-negative coccobacilli in obligate association with eukaryote cells.
While most of the known Rickettsia species are associated with terrestrial arthropods (especially ticks), some Rickettsia organisms have been identified in leeches, hydrae, protozoa, algae, and plants (MURRAY et al., 2016). Many Rickettsia species cause diseases in humans and animals, to which they are vectored by ticks, lice, fleas, or mites (PAROLA et al., 2013). Other Rickettsia species are classified as endosymbionts of their invertebrate hosts (MURRAY et al., 2016). This study investigated the occurrence of rickettsial infection in ticks collected from wild animals in two areas of Brazil. 
In August 2013 ticks were collected from a roadkilled capybara (Hydrochoerus hydrochaeris) in GuardaMor municipality $\left(17^{\circ} 42^{\prime} \mathrm{S}, 47^{\circ} 04^{\prime} \mathrm{W}\right)$, state of Minas Gerais, southeastern Brazil. In November 2014, ticks were collected from a six-banded armadillo (Euphractus sexcinctus) that was hand-captured in the Nhumirim Farm (18 $59^{\prime}$ 'S, 56 38'W), Corumbá municipality, state of Mato Grosso do Sul, Brazilian Pantanal (SISBIO - Wildlife research authorization \# 43259-1). In both cases ticks were brought alive to the laboratory, where they were identified to the species level following Barros-Batesti, Arzua, and Bechara (2006). Live ticks were checked individually for the presence of Rickettsia-like organisms, using the hemolymph test with Giménez staining (BURGDORFER, 1970 ), and then frozen at $-80^{\circ} \mathrm{C}$. Ticks that were found to be positive for Rickettsia-like organisms in the hemolymph test were submitted to rickettsial isolation in cell culture through the shell-vial technique, as previously described (LABRUNA et al., 2004). Briefly, cultures of Vero cells were inoculated with tick-body homogenates of each tick, and incubated at $28^{\circ} \mathrm{C}$. The percentage of Vero cells infected with rickettsiae was monitored by the use of Giménez's staining of cells scraped from each inoculated monolayer.

After the establishment of each isolate in the laboratory (i.e. at least three cell passages, with the prevalence of infected cells exceeding 90\%), rickettsial DNA was extracted from the infected cells using the DNeasy Blood \& Tissue kit (Qiagen, Chatsworth, CA, USA). The extracted DNA was tested by two polymerase chain reaction (PCR) protocols, one with primers CS-78 and CS-323, and another with primers CS-239 and CS-1069, which amplify two overlapping fragments of the rickettsial citrate synthase gene ( $g l t A$ ) (LABRUNA et al., 2004). PCR products were purified using ExoSAP-IT (USB Corp., Cleveland, OH, USA) and underwent DNA sequencing in an ABI automated sequencer (Applied Biosystems/Perkin Elmer, model ABI Prism 3500 Genetic, Foster City, CA, USA), and the resultant sequences were compared with GenBank data by BLAST analysis (http://blast.ncbi.nlm. nih.gov/Blast.cgi).

Ticks collected from a capybara were identified as 16 males and 16 females of Amblyomma dubitatum. Ticks collected from an armadillo were identified as two males of Amblyomma pseudoconcolor. By the hemolymph test, five A. dubitatum and two A. pseudoconcolor contained Rickettsia-like structures within their hemocytes. Attempts to isolate rickettsiae in Vero cell culture were performed individually with two hemolymph test-positive ticks, one A. dubitatum and one A. pseudoconcolor. Rickettsiae were isolated from one tick specimen of each tick species. The two isolates were successfully established in the laboratory with several passages, each one reaching $>90 \%$ infection of the cells. These isolates, designated as strains Ad-MG and Ap-MS, have been cryopreserved and deposited at the Rickettsial Collection of the Faculty of Veterinary Medicine, University of São Paulo, São Paulo, Brazil. Rickettsial DNA was successfully amplified and sequenced from the isolates. Fragments of 983 nucleotides (deposited in GenBank as KX020409) and 1055 nucleotides (GenBank: KX020408) were generated for the gltA gene of strains Ad-MG and Ap-MS, respectively. The two isolates differed from each other by only one nucleotide, and were identified as Rickettsia bellii through BLAST analysis. While the gltA fragment of strain Ad-MG was $100 \%$ identical to corresponding $R$. bellii sequences from GenBank (JQ906786, DQ865204, CP000087, U59716), the gltA fragment of strain Ap-MS was 99.9\% (1054/1055 nucleotides) identical to the same GenBank sequences. However, this single nucleotide polymorphism was a blind mutation, since the amino acid sequence of the gltA gene of strain Ap-MS was 100\% identical (351/351 amino acids) to $R$. bellii corresponding sequences in GenBank (Q59734, ABI96973, AFK91523, ACB54683). The remaining tick specimens were deposited as voucher specimens in the tick collection "Coleção Nacional de Carrapatos" (CNC), under accession numbers CNC-2519 (A. dubitatum) and CNC-3274 (A pseudoconcolor).

$R$. bellii is indeed the most common tick-associated Rickettsia species in the New World, where it was reported in the United States (PHILIP et al., 1983), El Salvador (BARBIERI; ROMERO; LABRUNA, 2012), Costa Rica (OGRZEWALSKA et al., 2015), Panama (ANDOH et al., 2015), Colombia (MIRANDA; MATTAR, 2014), Peru (OGRZEWALSKA et al., 2012), Brazil, and Argentina (LABRUNA et al., 2011). Until the present study, R. bellii had been reported to infect at least 24 tick species of both Ixodidae (22 species) and Argasidae (2 species) tick families (PHILIP et al., 1983; LABRUNA et al., 2011; BARBIERI et al., 2012; OGRZEWALSKA et al., 2012; MIRANDA; MATTAR, 2014; SOARES et al., 2015). While there have been several previous reports of $R$. bellii infecting $A$. dubitatum ticks (LABRUNA et al., 2011), here we provide the first report for A. pseudoconcolor, which increases to 25 the number of $R$. bellii-infected tick species. 
Such a vast array of tick hosts for $R$. bellii in different geographic areas may be an indication of recent horizontal transmission among ticks. While $R$. bellii has never been detected in vertebrate hosts, there has been serological evidence of animal infection or exposure to $R$. bellii (PACHECO et al., 2007). Currently, R. bellii is classified as an agent of unknown pathogenicity to humans (PAROLA et al., 2013). Since most of the $R$. bellii-infected tick species of South America are also human-biting ticks (GUGLIELMONE et al., 2006; LABRUNA et al., 2011), the pathogenic role of $R$. bellii to humans seems unlikely.

\section{Acknowledgments}

This work was supported by Fundação de Amparo à Pesquisa do Estado de São Paulo (FAPESP) and Coordenação de Aperfeiçoamento de Pessoal de Nível Superior (CAPES), Brazil.

\section{References}

ANDOH, M.; SAKATA, A.; TAKANO, A.; KAWABATA, H.; FUJITA, H.; UNE, Y.; GOKA, K.; KISHIMOTO, T.; ANDO, S. Detection of Rickettsia and Ehrlichia spp. in ticks associated with exotic reptiles and amphibians imported into Japan. PLoS ONE, v. 10, n. 7, p. 1-14, 2015. doi: 10.1371/journal.pone.0133700.

BARBIERI, A. R. M.; ROMERO, L.; LABRUNA, M. B. Rickettsia bellii infecting Amblyomma sabanerae ticks in El Salvador. Pathogens and Global Health, v. 106, n. 3, p. 188-189, 2012. doi: 10.1179\%2F2047773212Y.0000000022.

BARROS-BATESTI, D. M.; ARZUA, M.; BECHARA, G. H. Carrapatos de importância médico-veterinária da região neotropical : um guia ilustrado para idenfiticação de espécies. São Paulo: Vox/ICTTD-3/Instituto Butantan, 2006. $163 \mathrm{p}$.

BURGDORFER, W. Hemolymph test. A technique for detection of rickettsiae in ticks. The American Journal of Tropical Medicine and Hygiene, v. 19, n. 6, p. 10101014, 1970.

GUGLIELMONE, A. A.; BEATI, L.; BARROS-BATTESTI, D. M.; LABRUNA, M. B.; NAVA, S.; VENZAL, J. M.; MANGOLD, A. J.; SZABÓ, M. P. J.; MARTINS, J. R.; GONZÁLEZ-ACUÑA, D.; ESTRADA-PEÑA, A. Ticks (Ixodidae) on humans in South America. Experimental and Applied Acarology, v. 40, n. 2, p. 83-100, 2006. doi: 10.1007/s10493-006-9027-0.

LABRUNA, M. B.; MATTAR, S.; NAVA, S.; BERMUDEZ, S.; VENZAL, J. M.; DOLZ, G.; ABARCA, K.; ROMERO,
L.; SOUSA, R. de; OTEO, J. A.; ZAVALA-CASTRO, J. Rickettsioses in Latin America, Caribbean, Spain and Portugal. Revista MVZ Cordoba, v. 16, n. 2, p. 2435-2457, 2011.

LABRUNA, M. B.; WHITWORTH, T.; HORTA, M. C.; BOUYER, D. H.; MCBRIDE, J. W.; PINTER, A.; POPOV, V.; GENNARI, S. M.; WALKER, D. H. Rickettsia species infecting Amblyomma cooperi ticks from an area in the state of São Paulo, Brazil, where Brazilian spotted fever is endemic. Journal of Clinical Microbiology, v. 42, n. 1, p. 90-98, 2004. doi: 10.1128/ JCM.42.1.90-98.2004.

MIRANDA, J.; MATTAR, S. Molecular detection of Rickettsia bellii and Rickettsia sp. strain colombianensi in ticks from Cordoba, Colombia. Ticks and Tickborne Diseases, v. 5, n. 2, p. 208-212, 2014. doi: 10.1016/j. ttbdis.2013.10.008.

MURRAY, G. G. R.; WEINERT, L. A.; RHULE, E. L.; WELCH, J. J. The Phylogeny of Rickettsia using different evolutionary signatures: How tree-like is bacterial evolution? Systematic Biology, v. 65, n. 2, p. 265-279, 2016. doi: 10.1093/sysbio/syv084.

OGRZEWALSKA, M.; LITERÁK, I.; CAPEK, M.; SYCHRA, O.; CALDERÓN, V. Á.; RODRÍGUEZ, B. C.; PRUDENCIO, C.; MARTINS, T. F.; LABRUNA, M. B. Bacteria of the genus Rickettsia in ticks (Acari: Ixodidae) collected from birds in Costa Rica. Ticks and Tickborne Diseases, v. 6, p. 478-482, 2015. doi: 10.1016/j. ttbdis.2015.03.016. 
OGRZEWALSKA, M.; LITERAK, I.; CARDENASCALLIRGOS, J. M.; CAPEK, M.; LABRUNA, M. B. Rickettsia bellii in ticks Amblyomma varium Koch, 1844, from birds in Peru. Ticks and Tick-borne Diseases, v. 3, n. 4, p. 254-256, 2012. doi: 10.1016/j.ttbdis.2012.05.003.

PACHECO, R. C.; HORTA, M. C.; MORAES-FILHO, J.; ATAlibA, A. C.; PINTER, A.; LABRUNA, M. B. Rickettsial infection in capybaras (Hydrochoerus hydrochaeris) from São Paulo, Brazil: serological evidence for infection by Rickettsia bellii and Rickettsia parkeri. Biomedica: Revista del Instituto Nacional de Salud, v. 27, n. 3, p. 364-371, 2007.

PAROLA, P.; PADDOCK, C. D.; SOCOLOVSCHI, C.; LABRUNA, M. B.; MEDIANNIKOV, O.; KERNIF, T.; ABDAD, M. Y.; STENOS, J.; BITAM, I.; FOURNIER, P. E.; RAOULT, D. Update on tick-borne rickettsioses around the world: A geographic approach. Clinical Microbiology Reviews, v. 26, n. 4, p. 657-702, 2013. doi: 10.1128/CMR.00032-13.

PHILIP, R. N.; CASPER, E. A.; ANACKER, R. L.; CORY, J.; HAYES, S. F.; BURGDORFER, W.; YUNKER, C. E. Rickettsia bellii sp. nov.: a tick-borne rickettsia, widely distributed in the United States, that is distinct from the spotted fever and typhus biogroups. International Journal of Systematic Bacteriology,. 33, n. 1, p. 94-106, 1983. doi: 10.1099/00207713-33-1-94.

SOARES, H. S.; BARBIERI, A. R.; MARTINS, T. F.; MINERVINO, A. H.; DE LIMA, J. T.; MARCILI, A.; GENNARI, S. M.; LABRUNA, M. B. Ticks and rickettsial infection in the wildlife of two regions of the Brazilian Amazon. Experimental and Applied Acarology, v. 65, n. 1, p. 125-140, 2015. doi: 10.1007/s10493-014-9851-6. 